\title{
FOREIGN EXCHANGE RESTRICTIONS AND THE CONFLICT OF LAWS
}

PosT-WAR reparations and the need for economic rehabilitation created an inordinately heavy demand for foreign exchange among the nations defeated in the world war. ${ }^{1}$ Foreign loans granted to meet these demands served only to increase the debt burden. And when the sources of foreign capital dried up during the depression, the debtor nations lacked sufficient gold to continue servicing their debts. According to classical economic theory, the gold standard would function automatically to adjust the balance of payments and, where necessary, the course of trade between countries, in such a way that all payments might be made. ${ }^{2}$ But several factors had appeared to obstruct the process of natural adjustment. Increasing national regulation of industry and sterilization of creditor nations' gold supplies tended to make the international economic system less susceptible to gold movements. ${ }^{3}$ Furthermore, since the creditor nations erected tariff and quota barriers, ${ }^{4}$ and since the debtor nations themselves devoted their capital to such unproductive fields as rearmament, ${ }^{5}$ the latter were prevented from creating an export surplus with which to pay their foreign debts.

With rapidly diminishing gold supplies and no ready means of securing foreign exchange, a steadily increasing number of these foreign debtor countries have turned to governmental regulations to protect their currencies. ${ }^{\circ}$ Transfer prohibitions and governmental monopolies of foreign exchange are the most common expedients for maintaining gold and foreign exchange supplies. Regulations enacted by Germany during the last six years ${ }^{7}$ have achieved a special notoriety because of their effect upon large financial inter-

1. Harris, Gerarany's Foreign Indebtedness (1935) 1; aladden, Nadles aid Sautain, Adrerica's Experience as a Creditor Nation (1937) 166 ,

2. Salter, Recovery, the Second Effort (1932) 71; Tond, Tue Mfeczazisus or Exchange (1917) 131.

3. Madden, Nadler ANd SAUtan, op. cit. supra note 1, at 168, 176.

4. See Schacht, German Trade and German Debts (1934) 13 Forcign Afjairs 1; Summary of statements of Mr. Schacht, (1934) 139 Cossar. \& Fr. Crgori. 1318.

5. Securities and Exchange Consarission, Refort on Protective axid Reorganizatton Comarstrtees (1937) Part V, 419; Auld, The Dusues and Young Louns: Then and Now (1934) 13 Foresgn AfraIrs 6; Comstock, Blocked Marls and Ameriean Creditors, BarroN's, Jan. 29, 1934, p. 18.

6. See Publication of Reichsstelle für den Aussenhandel, DAS Devrseinzeczr DER Wert (1936) ; Ohlin, Mechanisms and Objectizes of Exchange Control (1937) 27 A2s. ECON. REv., Supp. 1, p. 141.

7. The most important German statutes in force at present are: Acts of Feb. 4, 1935, (1935) ReICHSGesetzBLATT I, 105; Dec. 19, 1936, (1936) REICrsscrsetzDLATt I, 1021; June 9, 1933, (1933) ReichsGesetzblatr I, 349; Mfay 27, 1937, (1937) Reicusgesetzblatt I, 600. See generally Einzig, Gerarany's Default (1934); Hhatre:stem, Devisennotrecti (1935-1936); Flad-Berghold-Fabracius, Das Neue Defisetrectit (1935-1937). 
ests. ${ }^{8}$ Their outstanding feature is the virtual prohibition, under grave penalty, ${ }^{9}$ of the payment of public and private foreign debts, ${ }^{10}$ including even payments made outside of Germany. Interest and principal due to foreign creditors must be paid to designated banking institutions in Germany, and these payments discharge the original debt. The foreign creditor may then expend the "blocked accounts" arising from repayment of principal only for certain narrowly limited purposes within Germany, ${ }^{11}$ and he receives the interest payments only in the form of long-term quasi-governmental debentures. ${ }^{12}$

The result has been to reduce the present foreign value of obligations owed by solvent German debtors ${ }^{13}$ as much as seventy-five per cent, ${ }^{14}$ while at the same time German creditors are assured repayment in undepreciated currency. Consequently it is not strange to find foreign creditors exerting pressure upon their governments to protect their interests. Those nations whose imports from Germany exceed their exports have been able to compel the satisfaction of their nationals' claims by threatening to impound the payment balances due to Germany. Under this stimulus Germany has signed clearing treaties by which these payment balances are utilized to liquidate German foreign debts. ${ }^{15}$ But the United States, whose exports to Germany exceed its imports, ${ }^{16}$ has been unable to make use of this weapon; and the

8. Germany's public and private long-term foreign indebtedness was estimated at 10.7 billions Reichsmarks (about 2.55 billions dollars) as of November, $1931 ; 7.2$ billions Reichsmarks (2.88 billions dollars) as of February, 1934; and 6.1 billions Reichsmarks (2.44 billions dollars) as of February, 1936. Statistiscues JAHrbucur rür das DeutSCHe ReICH (1936) 506. Americans are estimated by the State Department to hold about $\$ 1,800,000,000$ of German securities, of which about $\$ 1,170,000,000$ are long and medium term obligations affected by the German regulations. See Foreign Bonorolotrs Protective Council, Inc., Annual Report 1936, 405; (1934) 138 Comm. \& Fin. CHRoN. 4375.

9. In cases of "unscrupulous and egotistical" contraventions the penalty for a German citizen may be sentence of death and confiscation of property. Act of Dec. 1, 1936, (1936) Reichsgesetzblatt I, 999.

10. Short term debts to foreign banks are the subject-matter of the so-called standstill agreements. See HarRIs, op. cit. supra note 1 , at $\boldsymbol{Z 2}$.

11. See EinzIG, op. cit. supra note 7, at 111; HARRIS, op. cit. supra note 1 , at 32.

12. See Foretgn Bondholders Protective Council, Annual Report 1936, 511513; Poor's (1937) Fiscal Volume 73; PooR's (1937) Industrials 3129.

13. The solvency of the individual German debtors is generally not disputed. The difficulties are caused solely by the transfer restrictions. See Institute of International Finance, Bull. 72 (September 4, 1934) p. 7.

14. See Poor's (1937) Fiscal Volume 73 et seq.

15. See SEC REPORT, op. cit. sulpra note 5, at 425, 435 ct seq.; Ritter, Gcrmany's Experience with Clearing Agreements (1936) 14 ForeIGN Affatrs 465; Rosset, Lis Accords de Clcaring et les Obligations Contractuelles (1936) VERHANDLUNGEN DES SCHWETZERISCHEN JURISTENVEREINS II, 201a.

16. Foreign Bondholders' Protective Council, Annual Report 1934, 72. 
vigorous protests lodged with the German government by the Department of State have proved an unavailing substitute. ${ }^{17}$

Litigation involving these currency regulations may arise in two types of situations. A creditor whose government has not been able to compel satisfaction of his debt may attach the foreign assets of his German debtor. ${ }^{18}$ Or a creditor may sue his non-German debtor who has promised to make a payment in Germany now illicit under the German regulations. In each case the court is faced with the question whether the German prohibitions constitute a valid defense to the creditor's suit. ${ }^{10}$ While the answer may be affected by the general principles determining what law governs a contract, this Comment will confine itself to a discussion of the specific problems raised by the foreign currency statutes.

Contracts subject to American law. Even where the contracts in suit were, by their main points of contact, clearly localized in America, German corporate debtors have sought the shelter of their domestic statutes by invoking the rule subjecting corporations to the laws of their domicile,, 0 apparently in order to argue that the currency prohibitions made payment ultra vires. But since foreign laws have been accorded extra-territorial effect upon this theory only when they regulate the powers, organization, or relative rights of security holders of foreign corporations, ${ }^{21}$ the precedents would seem to indicate that the currency restrictions, which do not relate to these matters,

17. Aide-Memoires and notes of the State Department to the German Government, of June 27, July 17, October 13, November 25, 1934, Press Recrases of tuE DEpartarent of State, no. 248 p. 444 , no. 251 p. 60 , no. 263 p. 243 , no. 270 p. 325 ; Foreicit Bondholders Protective CouncIt, Annual Report (1935) 119 ; id. (1936) at 405.

18. An attempt was made to attach the German liner "Europa." See NEws-WEEk, Jan. 13, 1934, p. 23.

19. See generally Bendeems, Das Deutsche Devisenrecht uxd die Schwejz (1936) ; Huarburg, Einwirkung des Devisennotrechts auf PrivatrechtsherañatNisse (1936) ; Mayer, Dre Valutasceuld Nack Deutscheja Recht (1934); Neumann, Devisennotrecht und Internationales Privataecnt (1937) (the leading monograph); Bergmann, Le Réginte des Devises dans la Protiquc du Droit Intema-

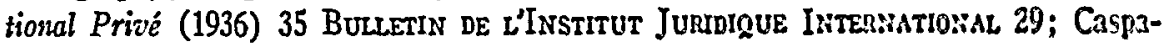
rius, Ungelöste Fragen aut dem Gebiet der Zieilrechtsfolgen der deutsehen Devisengesetzgebung (1936/37) 86 IHERINGs Jahrbücher 33, 67; Cohn, Curreney Restrictions and the Conflict of Laws (1936) 52 L. Q. Rev. 474; Dietrich, Die inlcmalionalrechilishe Bedeutung des Devisenrechts (1935) 64 Junistiscre WVocmenscmurt 3013; Domke, La Législation Allemande sur les Deaises en Droit International Privé (1937) 64 Journal du Drott Internationat (Clunet) 226; Wahle, Welche wührungsrechtlichen Bestimmingen empfehlen sich auf dem Gebiete des Prizatrechis?; (1933) Secrsten DeUtscher Juristentag IN Der Tschechoslowaket, Gutachte: 181.

20. Canada Southern Ry. v. Gebhardt, 109 U. S. 527 (1883); Sliosherg v. New York Life Ins. Co., 244 N. Y. 482, 155 N. E. 749 (1927); Doyle v. French Telegraph Cable Co., 244 App. Div. 586, 280 N. Y. Supp. 281 (1st Dep't 1935).

21. Second Russian Ins. Co. v. Miller, 268 U. S. 552 (1925); Guinness v. Phoenix Ass. Co., Ltd., 196 App. Div. 495, 188 N. Y. Supp. 137 (1st Dep't 1921). 
are not applicable. ${ }^{22}$ Neither logic nor policy afford any warrant for according extra-territorial effect to currency restrictions, which affect individuals and corporations alike, merely because the debtor happens to be incorporated.

There is a second method by which German debtors, both corporate and individual, have tried to invoke the currency restrictions as a defense. Granting the general proposition that American law governs the obligation, the debtors have argued that they will be punished by the German courts for any voluntary payment made either at home or abroad. The gravity of this risk is claimed to render payment virtually impossible and therefore to excuse performance under conventional contract doctrines. ${ }^{23}$ Whether the danger is really so great as to render performance impossible may well be doubted, for an involuntary payment, compelled by judgment and execution, is not within the purview of the German penal provisions. ${ }^{24}$ But the existence of impossibility, actual or otherwise, would seem to be irrelevant, since the rule is generally said to be that impossibility due to foreign law is no defense, at least where performance is due in the forum. ${ }^{25}$ It has been suggested that the reason for this rule is an historical accident. ${ }^{20}$ The leading cases, announcing that impossibility due to foreign law is no defense, were decided before any type of impossibility was a defense and have since been regularly followed. ${ }^{27}$ But a sounder basis for the rule may be found in jurisdictional theories of the conflict of laws. It is a familiar principle of interstate law that the legislature of one state may not by threat of punishment

22. Central Hanover Bank \& Trust Co. v. Siemens \& Halska A. G., 15 F. Supp. 927 (S. D. N. Y. 1936), aff'd, 84 F. (2d) 993 (C. C. A. 2d, 1936), cert. dctiicd, 299 U. S. 585 (1936).

23. Foreign prohibitions against trading with the enemy, otherwise inapplicable, constitute a factual impossibility of performance. German Supreme Court, June 28, 1918, 93 Entscheidungen des Reichsgerichts in Zivilsachen 182. But see cases cited infra note 59.

24. The defense of impossibility has been refused on this ground. Appeldoorn v. Osram G. m. b. H., District Court of Amsterdam, March 22, 1935, [1935] Nederlandsche Jurisprudentie 590; Nederlandsche Vakvereenigingen v. Bank der Deutschen Arbeit, District Court of Amsterdam, June 23, 1936, [1937] Nederlandsche Jurisprudentic 34; Zenith A. T. v. Beer, Sondheimer \& Co., Municipal Court of Oslo, Feb. 13, 1936, Sjöfartstidende of Feb. 19, 1936; Rheinische Grundstückshandelsgeselfschaft. m. b. H. v. Aktiengesellschaft für Immobilienwerte, Swiss Supreme Court, Oct. 8, 1935, 61 Entscheidungen des Schweizerischen Bundesgerichts II, 242.

25. Standard Silk Dyeing Co. v. Roessler \& Hasslacher Chem. Co., 244 Fed. 250 (S. D. N. Y. 1917); Tweedie Trading Co. v. McDonald Co., 114 Fed. 985 (S. D. N. Y. 1902); Compagnie Universelle v. United States Service Co., 84 N. J. Eq. 604, 95 Atl. 187 (Ch. 1915), aff'd, 85 N. J. Eq. 601, 96 Atl. 292 (1916); Krulewitsch v. National Importing \& Trading Co., 195 App. Div. 544, 186 N. Y. Supp. 838 (1st Dep't 1921); Trinidad S. \& T. Co. v. Alston \& Co. [1920] A. C. 888; cf. notes 26, 30, infra.

26. See 3 Williston, Contracts (1920) 3295; Comment (1921) 34 Harv. L. Rev. 319 ; cf. Restatement, Contracts: (1932) $\$ 458$, comment c., $\$ 461$.

27. See 3 WrLliston, Contracts (1920) 3295, n. 55. 
control its citizens' actions in other states. ${ }^{28}$ A similar rule governs the distribution of legislative jurisdiction in international situations even though there is no constitution to enforce it. Although each sovereign has the power, respected by its own courts, to impose restrictions on the conduct of its citizens abroad, the courts of other countries are reluctant to enforce within their own jurisdictions the prohibitions imposed by foreign legislatures.? Consequently, the courts have quite generally refused to sanction the infiltration of foreign prohibitions by stating that they create "impossibility." 3o Even contractual exemption clauses such as a promise to pay "so far as lawfully possible" have been strained in vain to include the foreign currency regulations. ${ }^{31}$

But impossibility occasioned by foreign law may be a defense in some situations. Where suit is brought upon a contract subject to American law but calling for payment in Germany, the currency restrictions would seem to be an excuse for non-performance. ${ }^{32}$ Debtors may rely on the foreign prohibitions as causing impossibility even where acts which in the contemplation of both parties had to be done abroad preparatory to performance have become illegal. Thus the performance of a contract for the delivery of specific or fungible goods may be excused if both parties contemplated that the promisor was to rely on exportation from a foreign country which subsequently forbids the export. ${ }^{33}$ Similarly, the repayment of a loan would seem to be impossible, if the foreign debtor has promised only to remit the payment from his domicile to this country and the domicile subsequently has enacted transfer prohibitions. ${ }^{34}$

The rationalization for the rule is said to be that the forum will not order the performance of an act which would be illegal at the place where it must

28. Allgeyer v. Louisiana, 165 U. S. 578 (1897); Bothwell v. Buckbee, Arears Co., 275 U. S. 274 (1927).

29. Second Russian Ins. Co. v. Miller, 268 U. S. 552 (1925); Southern P. R. R. of Mexico y. Gonzales, 48 Ariz. 260, 61 P. (2d) 377 (1936); Guinness v. Phoenix Ass. Co., Ltd., 196 App. Div. 495, 188 N. Y. Supp. 137 (1st Dep't 1921) ; see Furness, Withy \& Co. v. Rederiaktiebolaget Banco [1917] 2 K B. 873, 876.

30. Perry v. North German Lloyd, 150 Mrisc. 73, 268 N. Y. Supp. 525 (Mrunic. Ct. N. Y., 1934); Sheppard v. Hamburg-Amerikanische Paketialirt A. G., N. Y. L. J., March 14, 1934, p. 1232, col. 2 (Sup. Ct.) ; Glynn v. United Steel Works Co., 160 Mfise. 405,289 N. Y. Supp. 1037 (Sup. Ct. 1935) ; Ararks v. United Steel Works Co., 160 Alisc. 678, 289 N. Y. Supp. 1035 (N. Y. City Ct., 1935) ; cf. Starr v. Chase National Banl;, N. Y. L. J., Sept. 21, 1936, p. 771, col. 6 (Sup. Ct).

31. Marks v. United Steel Works Corp. and Glynn v. United Steel Works Corp., both cited supra, note 30 .

32. De Beéche v. South American Stores [1935] A. C. 148 (the court failed to discuss which law governed the contract); cf. St. Pierre v. South American Stores [1937] 1 All Eng. Rep. 206.

33. Texas Co. v. Hogarth Shipping Co., 256 U. S. 619 (1921); Doulton \& Co. v. Corporation of Miadras [1920] W. N. II 221.

34. Mayer v. Hungarian Commercial Bank, U. S. Dist. Ct., E. D. N. Y., July 28, 1937. 
be performed..$^{35}$ But the rule apparently is of wider scope, for it operates to discharge debtors in those instances where the contract is still executory. ${ }^{30}$ On the other hand, where a loan has been granted or goods sold, courts have recognized the fact that it is unfair to leave the creditor without a remedy, and have allowed him a recovery on the theory of restitution. ${ }^{37}$ This result is open to several objections. First, even though the contract is subject to the law of the forum, it may be argued that matters concerning the terminattion are governed by the law of the place of performance ${ }^{38}$ which in this case discharges the debtor. But this rule has only presumptive force. ${ }^{30}$ Practical considerations and the dominating contacts with the forum, at least when the plaintiff is a citizen of the forum, would seem to be sufficient reason for overcoming the presumption. Secondly, since granting restitution in loan transactions actually operates to remove the place of performance from one country to another, ${ }^{40}$ this remedy may work hardship upon the debtor. But as the creditor will be left without remedy in the absence of such relief, a judicial modification of the contract terms would seem proper after a careful evaluation of the interests of both parties.

Contracts subject to foreign law. Other considerations obtain in cases where the relations of the parties to the contract would ordinarily be governed by German law. If the discharge of the debtor was authorized by the German currency restrictions, a complete defense to suit in other countries would ordinarily be available to the debtor in the absence of any other factors. ${ }^{41}$ The prohibitions cannot be brushed aside even by the debtor's express

35. Ralli Brothers v. Compania Naviera Sota y Aznar [1920] 2 K. B. 287; Kursell v. Timber Operators \& Contractors, Ltd. [1927] 1 K. B. 298; see ANson, Contracts (Corbin's ed. 1930) 472; Restatement, Conflict of Laws (1934) $\$ 360$.

36. Cf. Mayer v. Hungarian Commercial Bank, U. S. Dist. Ct., E. D. N. Y., July 28, 1937.

37. Cf. American Union Bank v. Swiss Bank Co., 40 F. (2d) 446 (C. C. A. 2d, 1930) ; Aachen \& Munich Fire Ins. Co. v. Guaranty Trust Co., 27 F. (2d) 674 (C. C. A. 2d, 1928); Richard v. Crédit Suisse, 242 N. Y. 346, 152 N. E. 110 (1926); Sokoloff v. National City Bank, 239 N. Y. 158, 145 N. E. 917 (1924).

38. See 2 Beale, Conflict of Laws (1935) 1272; Restatenent, Conflict of Laws (1934) §358. But see Cook, Contracts and the Conflict of Lazes (1936) 31 ILx. L. REv. 150 et seq.

39. See Louis Dreyfus v. Paterson Steamships, Ltd, 43 F. (2d) 824 (C. C. A. 2d, 1930) ; Compania de Inversiones Internacionales v. Industrial Mortgage Bank of Finland, 269 N. Y. 22, 198 N. E. 617 (1935).

40. Foreign jurisdictions have changed the place of payment in like manner but have not resorted to the doctrine of restitution. German Supreme Court, Sept. 19, 1923, 107 Entscheidungen des Reichsgerichts in Zivilsachen 121; Skandia Ins. Co. v. Swedish Nat'1 Debt Office, Swedish Court of Appeals, April 16, 1935, 33 BuLzETN DE L' INSTITU'T JURIDIQUe INTERNATIONAL 142, 145.

41. St. Pierre v. South American Stores, Ltd. (1937) 1 All Eng. Rep. 206; German Supreme Court, July 1, 1930, (1930) Die Deutsche Rechtsprechung auf dem Gebiet des internationalen Privatrechts 49 no. 15; Austrian Supreme Court, Apr. 24, 1936, 18 Rechtsprechung 146 no. 224; March 11, 1936, 18 Rechtsprechung 67 no. 95 scmble; cf. De Beéche v. South American Stores, Ltd. [1935] A. C. 148. 
promise. ${ }^{2}$ Notwithstanding this general rule, there are two methods by which the creditor might secure satisfaction of his debt.

First, the debt may be immunized against the prohibitions in force at the debtor's domicile by a stipulation in the contract that the creditor may, at his option, demand payment not only at the debtor's residence but also at designated places in other countries. Option of place clauses, not infrequent in international bond issues, are ordinarily coupled with a provision that payment at the alternative places shall be made in the respective local currencies either at a fixed or at the current rate of exchange. ${ }^{43}$ In either case a creditor demanding payment at one of the alternative places removes his claim from the restrictions in force at the debtor's domicile. For the rule that matters concerning the termination of an obligation are determined by the laws of the place of performance, though not always an unfailing guide, is supported here by the very purpose of the option clause, which is to protect the foreign investor against the vicissitudes of the debtor's domestic law. ${ }^{44}$ It has been suggested that an option to demand payment in another currency at the current rate rather than at a fixed rate of exchange is merely for the "convenience" of the bondholder in obviating the necessity of going to the debtor's domicile to collect payment and therefore is not determinative of the applicable law. ${ }^{45}$ But this argument overlooks the fact that in the absence of such a clause the bondholder could cash his matured bonds and coupons through his own banker at no substantial cost, since the "cur-

42. Austrian Supreme Court, Sept. 25, 1934, 16 Rechtsprechung 206. But neither a surety nor the owner of real estate pledged in the creditor's country for the foreign debt may avail himself of the principal debtor's defense based on his domiciliary prohibitions. Compagnie Générale v. Simon Herzig \& Sons, 89 Mfisc. 573, $153 \mathrm{~N}$. Y. Supp. 717 (Sup. Ct. 1915) ; Nathan-Institut A. G. v. Schweizerische Bank für Kapitalanlagen, Swiss Supreme Court, Sept. 18, 1934, 60 Entscheidungen des Schweizerischen Bundesgerichts II, 294; Compagnie l'Urbaine v. Etablissement Bernard et Devavrin, Appellate Court of Paris, Nov. 8, 1935, 34 Bulletrn DE r'INSTItur Juridrque IriterNATIONAL 260 no. 9364.

43. See Nussbaum, Mrultiple Currency and Index Clauses (1936) 84 U. of PA. L. REv. 569; Rabel, Golddollaranleihen mit Vereinbarung des New Yorker Rechts (1936) 10 Zettschrtft für Ausländisches und Internationales Privatrectit 492, 497 al seq.; Seignol, L'Option de change et L'Optron de pLACE (1935).

44. Anglo-Continentale Treuhand A. G. v. St. Louis S. W. Ry., 81 F. (2d) 11 (C. C. A. 2d, 1936), cert. denied, 298 U. S. 655 (1936); King v. International Trustec [1937] A. C. 500; German Supreme Court, Sept. 20, 1920, 100 Entscheidungen des Reichgerichts in Zivilsachen 79; see RestatEarent, Confrict of LAws (1934) \$\$356, 360.

45. Appellate Court of Cologne, Sept. 13, 1935, [1936] Jurisnscae WocraniSCHRIFT 203; N. V. Koninklijke Nederlandsche Mrij. v. Vereeniging voor den Effectenhandel, Appeliate Court of s'Gravenhage, Netherlands, Jan. 14, 1935, [1935] Nederlandsche Jurisprudentie 119, reversed, Netherlands Supreme Court, March 13, 1935 [1936] Nederlandsche Jurisprudentie 497. Contra: P. P. G. C. v. Sociëtés Siemens et Halske et Siemens Schuckertwerke, Tribunal Civil de la Seine, July 23, 1936, 3 Nouvelie Revue de Droit International, Prive 792. 
rent buying rate of exchange," which forms the basis of computation according to the option clause, includes the costs of collection at the debtor's domicile. ${ }^{46}$ Consequently it would seem that the real purpose of both types of clauses is to impose the risk of transferability on the debtor.

Secondly, a creditor might possibly avoid the general rule that a discharge authorized by German law is a valid defense by arguing that the debtor may not rely on that law because it violates the public policy of the forum. ${ }^{47}$ Since public policy is at best a vague concept, it has been recognized that unless checked it may be destructively applied to interfere with the normal play of private international law principles. Mere divergence from domestic law therefore does not justify exclusion of the foreign law $; 8$ nor does identity of the foreign with the domestic law guarantee the former against exclusion. ${ }^{40}$ Rather to justify exclusion the foreign statute must interfere with an in-portant interest of the forum.

When suit is brought by an American creditor, it requires no close consideration of the currency restrictions to conclude that they adversely affect an important American interest, for their main purpose is to protect the German national economy at the expense of foreign creditors. . $^{50}$ This treatment of American creditors is not only repugnant to the spirit of the equal protection clauses of the Federal Constitution, but has met with the express condemnation of the Department of State. ${ }^{61}$ Although foreign moratoria ${ }^{62}$ and gold clause abrogations ${ }^{53}$ have in some cases been found reconcilable with the forum's public policy, these cases should not be determinative of

46. See Guaranty Trust Co. of New York, How Business with Fonetgn Countries is Financed (1921) 8-9.

47. See Central Hanover Bank \& Trust Co. v. Siemens \& Halske A. G., 15 F. Supp. 927 (S. D. N. Y. 1936), aff'd, 84 F. (2d) 993 (C. C. A. 2d, 1936), cert. dctict, 299 U. S. 585 (1936); Glynn v. United Steel Works Co., 160 Misc. 405, 289 N. Y. Supp. 1037 (Sup. Ct. 1935). For foreign holdings see NeumanN, op. cit. supra note 19 , at 35 et seq.

48. Comment (1933) 33 Cot. L. Rev. 508, 518.

49. German Supreme Court, May 28, 1936, (1936) JuRistische Wochenscirrift 2058; see NeumanN, op. cit. supra note 19, at 47; Wolfr, Internationales PrivatRECHT (1933) 43. Contra: Austrian Supreme Court, Sept. 25, 1934, (1934) Rechtsprechung 206.

50. It has been urged that the German legislation is not directed against cilizens of foreign countries but against foreign residents regardless of their citizenship. Dietrich, supra note 19, at 3014 .

51. See notes of the Department of State to the German Government, note 17, supra. The attitude of the State Department carries great weight in determining public policy. See United States v. Belmont, 301 U. S. 324 (1937), (1937) 47 YALE L. J. 292, 294.

52. See Lorenzen, Moratory Legislation Relating to Bills and Notes (1919) 28 YALE L. J. 324; Ghiron, Moratorie e regressi nel diritto internazionale privato (1915) Rivista Di Diritio Internazionale 152.

53. See Nussbaum, Comparative and International Aspects of American Gold Clause Abrogation (1934) 44 YALE L. J. 53 ; (1937) 46 Y ALE L. J. 891 ; Rabel, supra note 43. 
the problem here involved, for currency restrictions perform an entirely different function. Moratoria and gold clause enactments are intended to aid the individual debtor by extending additional time for payment or by reducing the principal amount, regardless of the nationality of the creditor. On the other hand, currency restrictions, since they do not relieve the debtor of his obligation but rather direct him to pay a German depositary, aid the individual debtor only in so far as they protect the national currency and prevent a financial collapse. Moratoria and gold clause legislation apply equally to creditors of all nationalities, while the currency regulations discriminate against foreign creditors. American courts cannot be indifferent when protection for a foreign economy is thus sought at the expense of American creditors. ${ }^{54}$

Although public policy would probably be invoked to aid American suitors, no exertion of public policy is to be expected in behalf of foreign creditors seeking to escape the currency restrictions of their own country. ${ }^{.5}$ They are not the victims of discrimination; and to protect them against the general laws of their own government would infringe on the comity due to the foreign nation. $^{56}$ But between the extremes of safeguarding the domestic interests and of refraining from interference with the foreign government lies the penumbra created by the "relativity" of public policy." There is no American

54. Cf. Williams v. Bruffy, 96 U. S. 176, 183-4 (1877); Blanchard v. Russell, 13 Mass. 1, 6 (1816) ; Story, Conflict of Laws (8th ed. 1883) 478, 481. Foreign jurisdictions have refused to recognize currency restrictions on the ground that they are "political" or "penal" statutes. Geissmann v. Benzinger, Appellate Court of Colmar, France, Feb. 16, 1937, [1937] Revue Juridique d'Alsace et de Lorraine 469. For additional cases see NEUMrans, op. cit. supra note 19 , at $3,17$.

55. The protection afforded by American public policy has frequently been denied to foreigners. Heine v. New York Life Insurance Co., 50 F. (2d) 382 (C. C. A. 9th, 1931); Dougherty v. Equitable Life Ass. Soc., 266 N. Y. 71, 193 N. E. 897 (1934); see United States v. Belmont, 301 U. S. 324, 327 (1937). But the restriction is not an absolute one. Holtzer v. Deutsche Reichsbahngesellschaft, 159 Afise 830, $290 \mathrm{~N}$. Y. Supp. 181 (Sup. Ct. 1936), aff'd, N. Y. L. J., Oct. 16, 1937, p. 1182, col. 5 (1st Dep't). And by assignment to an American citizen, a non-resident alien's claim may secure the protection of American public policy. Frenkel \& Co. v. L'Urbaine Fire Ins. Co. of Paris, 251 N. Y. 243,167 N. E. 430 (1929).

56. De Beéche v. South American Stores, Ltd. [1935] A. C. 148; St. Pierre v. South American Stores, Ltd. [1937] 1 All Eng. Rep. 206 (in neither case was public polic: argued); Appellate Court of Hamburg, May 16, 1929, (1930) Hanseatische Rechts-und Gerichtszeitschrift B 743. But see Bickel \& Cie v. Schürch, Swiss Supreme Court, Feb. 19, 1936, 62 Entscheidungen des Schweizerischen Bundesgerichts II, 103; Bronstein v. Banque Russo-Asiatique, Appellate Court of Paris, June 30, 1933, 60 Jounsist du DROIT international (Clunet) 963 ; Neunana, op. cit. supta note 19, at 50 et seq., 113.

57. See Kosters, Public Policy in Prizate International Law (1920) 29 YAle L J. 745, 757-8; Comments (1923) 32 YALE L. J. 471, 473, (1936) 45 YALE L. J. 1463, 1470; 1 Kahn, Abeandlungen zuar internationalen Privatrecert (1928) 161 ; Nussbauss, Deutches Internationales Privatrecht (1932) 63. 
precedent determining whether the citizen of a third country may invoke the forum's public policy for protection against the discrimination by the debtor's domiciliary statutes. ${ }^{58}$ This much may, however, be suggested. Neutrality of the forum during the world war was a sufficient ground to reject the belligerents' prohibitions against trading with the enemy, even where a non-citizen of the forum was benefited by the rejection.50 Economic neutrality, it would seem, should dictate the same result with respect to foreign regulations that are wielded as the weapons of economic warfare.

58. Foreign courts have at times allowed non-citizens of the forum to invole the forum's public policy against the German currency statute. Zenith A. T. v. Baer, Sondheimer \& Co., Municipal Court of Oslo, Feb. 13, 1936, Sjöfartstidende of Feb. 19, 1936 (Dutch plaintiff); District Court of Zürich, July 3, 1934, File No. 2542/1933, cited by NeumanN, op. cit. supra note 19, at 57 (Dutch plaintiff).

59. Compagnie Universelle v. United States Service Co., 84 N. J. Eq. 604, 95 Atl. 187 (Ch. 1915), aff'd, 85 N. J. Eq. 601, 96 At1. 292 (1916) ; Bryce, White \& Sons, Ltd. v. Henkel \& Co., Netherlands Supreme Court, Nov. 2, 1917, (1919) 46 JournaL du Droit International (Clunet) 425; La Nationale v. Biermann, Swiss Supreme Court, Apr. 17, 1916, 42 Entscheidungen des Schweizerischen Bundesgerichts II, 179; see cases cited in Niboyet, De l'Effet en Pays Neutre des Mestures de Gucrre (1920) 16 Revue de Droit International Privé et de Droit Pénal International (Darras. LAPRADELLE) 248. 